\title{
PERMAINAN EDUKASI PSIKOSOSIAL DI DESA AIK BERIK KECAMATAN BATUKLIANG UTARA KABUPATEN LOMBOK TENGAH
}

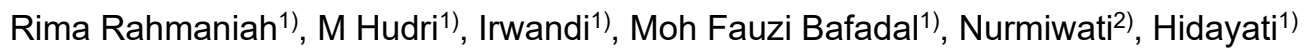 \\ 1)Program Studi Pendidikan Bahasa Inggris, FKIP, Universitas Muhammadiyah Mataram, Mataram, Indonesia \\ 2)Program Studi Pendidikan Bahasa Indonesia, FKIP, Universitas Muhammadiyah Mataram, Mataram, Indonesia \\ Corresponding author : Rima Rahmaniah \\ E-mail : rimarahmaniah172@gmail.com
}

Diterima 29 April 2020, Disetujui 8 Mei 2020

\begin{abstract}
ABSTRAK
Bermain, dari segi pendidikan adalah kegiatan permainan menggunakan alat permainan yang mendidik serta alat yang bisa merangsang perkembangan aspek kognitif, sosial, emosi, dan fisik yang dimiliki anak atau yang disebut dengan permainan edukatif. Adams (1975) berpendapat bahwa permainan edukatif adalah semua bentuk permainan yang dirancang untuk memberikan pengalaman pendidikan atau pengalaman belajar kepada para pemainnya, termasuk permainan tradisional dan moderen yang diberi muatan pendidikan dan pengajaran. Maka guna mengurangi trauma anak pada dampak bencana gempa pada tahun 2018 lalu, tim pengabdian bersama mahasiswa melaksanakan kegiatan pengabdian sebagai kegiatan psikososial dengan mengajak dan mengajar anak-anak terdampak tersebut dengan memberikan permainan edukatif dengan tahapan kegiatannya dimulai dari pemutaran film animasi gempa bumi, sesi tanya jawab, dan bermain edukasi untuk mengurangi trauma anak mengenai kejadian bencana yang terjadi di tahun 2018 lalu untuk meningkatkan pengetahuan, keterampilan dan self awareness anak usia sekolah sampai menengah yang ada di desa Aik Berik Kecamatan Batukliang Utara Kabupaten Lombok Tengah. Kegiatan ini akan dilakukan selama 8 (delapan) pekan dalam 2 (dua) bulan dengan menggunakan metode observasi atau pengamatan langsung, dan metode tindakan. Target hasil capaian dan simpulan dalam kegiatan ini sebagai berikut: a) Adanya pemahaman tentang mitigasi bencana pada anak-anak dan masyarakat yang akan menemani anak-anak mereka untuk meningkatkan self awareness mereka tentang bencana, b) Dimilikinya pengembangan pengetahuan, ketrampilan dengan menggunakan permainan edukatif untuk mengurangi trauma akan dampak gempa yang terjadi tahun 2018 lalu, dan c) Dimilikinya pemahaman tentang kesiapsiagaan akan mitigasi bencana yang bertujuan pengurangan dampak bencana atau usaha-usaha yang dilakukan untuk mengurangi korban ketika bencana terjadi baik korban jiwa maupun harta
\end{abstract}

Kata kunci : permainan edukasi; psikososial.

ABSTRACT
In terms of education, playing is an activity by using games that can stimulate the development of cognitive, social, emotional, and physical aspects of a child or what is called an educational game. Educational games are all forms of games designed to provide educational experiences or learning experiences to the players, including traditional and modern games that are given educational and teaching content. So in order to reduce child trauma on the impact of the earthquake in 2018, the team of devotees along with students carried out community service activities as a psychosocial activity by inviting and teaching affected children by providing educational games with stages of activities starting from the screening of earthquake animated films, question answer sessions, and education games to reduce child trauma regarding disasters that occurred in 2018 and to improve the knowledge, skills and self awareness of school-to-middle-aged children in the Aik Berik village, Batukliang Utara District, Lombok Tengah District. This activity would be carried out for 8 (eight) weeks in 2 (two) months using the observation method or direct observation, and the action method. The target and conclusion in this activity are as follows: a) An understanding of disaster mitigation for children and the community that will accompany their children to increase their self-awareness about disasters, b) Having the knowledge development and skills by using educational games to reduce trauma to the effects of the earthquake that occurred last 2018, and c) Having an understanding of disaster mitigation preparedness aimed at reducing the impact of disasters or efforts made to reduce casualties when disasters occur both fatalities and property.

Keywords : educational game; psychosocial. 


\section{PENDAHULUAN}

Dunia anak adalah dunia bermain. Dengan bermain, anak akan memperoleh pelajaran yang mengandung aspek perkembangan kognitif, sosial, emosi dan perkembangan fisik. Bermain merupakan sarana untuk menggali pengalaman belajar yang sangat berguna untuk anak. Bermain juga dapat menjadi sarana untuk mengembangkan kreativitas dan daya cipta, karena bermain adalah sumber pengalaman dan uji coba. Bermain, dari segi pendidikan adalah kegiatan permainan menggunakan alat permainan yang mendidik serta alat yang bisa merangsang perkembangan aspek kognitif, sosial, emosi, dan fisik yang dimiliki anak atau yang disebut dengan permainan edukatif.

Permainan edukatif adalah semua bentuk permainan yang dirancang untuk memberikan pengalaman pendidikan atau pengalaman belajar kepada para pemainnya, termasuk permainan tradisional dan moderen yang diberi muatan pendidikan dan pengajaran Atas dasar pengertian itu, permainan yang dirancang untuk memberi informasi atau menanamkan sikap tertentu, misalnya untuk memupuk semangat kebersamaan dan kegotongroyongan, termasuk dalam kategori permainan edukatif karena permainan itu memberikan pengalaman belajar kognitif dan afektif (Adams, 1975). Dengan demikian, tidak menjadi soal apakah permainan itu merupakan permainan asli yang khusus dirancang untuk pendidikan ataukah permainan lama yang diberi nuansa atau dimanfaatkan untuk pendidikan. Menurut John Dewey, tujuan pendidikan adalah membentuk anak menjadi anggota masyarakat yang baik, yaitu anggota masyarakat yang mempunyai kecakapan praktis dan dapat memecahkan problem sosial sehari-hari dengan baik.

Pendidikan merupakan upaya dasar yang dilakukan oleh keluarga, masyarakat, serta pemerintah, dengan melalui pengajaran atau latihan, kegiatan bimbingan, yang berlangsung di dalam sekolah dan di luar sekolah sepanjang hidupnya. Tujuan pendidikan adalah untuk mempersiapkan anak didik supaya mampu memainkan peranan pada berbagai kondisi lingkungan hidup dengan tepat di waktu yang akan dating (Mudyaharjo,2010). Sedangkan, tujuan dari pendidikan Montessori (1870-1952) adalah perkembangan individu. Program-program Montessori lebih mengkonsentrasikan pada pengembangan keterampilan-keterampilan intelektual umum dari pada konsep-konsep mata pelajaran tertentu. Sekolah-sekolah Montessori sering menggunakan perabot sekolah yang disesuaikan dengan ukuran peserta didik dan materi belajar yang dirancang khusus. Penekanannya adalah pada jenis latihan yang disesuaikan dengan perkembangan anak yang akan dikembangkan. Penekanannya adalah pada bagian dari program Head Start menyeluruh. Head Start merupakan bagian dari program Presiden Lyndon Johnson dalam memerangi kemiskinan, suatu upaya untuk membuat terobosan memutus lingkaran kemiskinan. Idenya adalah memberikan kesempatan kepada anak yang kurang beruntung untuk memulai sekolah formal dengan keterampilan-keterampilan praakademik dan sosial yang sama dengan anak kelas menengah

Oleh karena itu tim pelaksana membuat pengabdian yang bertujuan untuk mengembangkan semua potensi yang dimiliki anak dan melekatkan dasar kearah perkembangan sikap, pengetahuan, ketrampilan dan daya cipta untuk menyesuaikan diri dengan lingkungannya dan untuk pertumbuhan dan perkembangan selanjutnya denga menggunakan permainan edukatif. Dengan harapan pengetahuan yang didapat ditularkan pada lingkungan sekitar dalam rangka mengurangi risiko bencana. Maka guna mengurangi trauma anak pada dampak bencana gempa pada tahun 2018 lalu, maka tim pengabdian bersama mahasiswa melaksanakan kegiatan pengabdian dengan mengajak dan mengajar anak-anak terdampak tersebut dengan memberikan permainan edukatif dengan tujuan seperti di atas. Pada kegiatan tersebut, akan diberikan pemutaran film animasi gempa bumi yang telah dibuat oleh MDMC (Muhammadiyah Disaster Management Centre) Pusat dengan menayangkan beberapa kejadian bencana seperti gempa bumi, gunung meletus, banjir, tanah longsor, dan kebakaran yang kesemuanya dikemas dalam sebuah video yang siap untuk ditayangkan dengan durasi waktu pemutaran video, sesi tanya jawab dan bermain edukasi untuk mengurangi trauma anak mengenai kejadian bencana yang terjadi pada bulan Agustus sampai beberapa waktu kemudian di tahun 2018 lalu untuk meningkatkan pengetahuan, keterampilan dan self awareness anak.

\section{METODE}

Kegiatan ini telah dilakukan selama 12 (duabelas) pekan dalam 3 (tiga) bulan dengan menggunakan metode observasi atau pengamatan langsung (adalah melihat dan mendengarkan peristiwa atau tindakan yang dilakukan oleh orang-orang yang diamati, kemudian merekam hasil pengamatannya dengan catatan atau alat bantu lainnya) dalam hal ini yang dilakukan oleh tim pengabdian 
adalah metode observasi partisipatoris atau pengamatan langsung di lapangan, metode tindakan (dalam hal ini tindakan yang dimaksudkan adalah menggunakan metode role play is any speaking activity when you either put yourself into somebody else's shoes, or when yoy stay in your own shoes but put yourself into an imaginary situation (Ladousse, 1987 in Joanna Budden, 2006) yang artinya adalah kegiatan berbicara dimana pemain dapat berperan menjadi dirinya sendiri tetapi berimajinasi dalam berbagai situasi.

Pelaksanaan kegiatan pengabdian kepada masyarakat ini akan dilakukan pada anak-anak usia dini, anak-anak usia Taman Kanak-kanak (kindergarten), Sekolah Dasar (elementary) dan anak-anak Sekolah Menengah Pertama (junior high school) yang ada di desa Aik Berik Kecamatan Batukliang Utara Kabupaten Lombok Tengah kearah timur dari kota Mataram dan untuk menuju desa ini berjarak 34,5 km dengan menempuh sekitar 1 jam 10 menit menuju arah Labuhan Lombok, Lombok Timur melalui jalan Raya Mataram, Kotamadya Mataram.

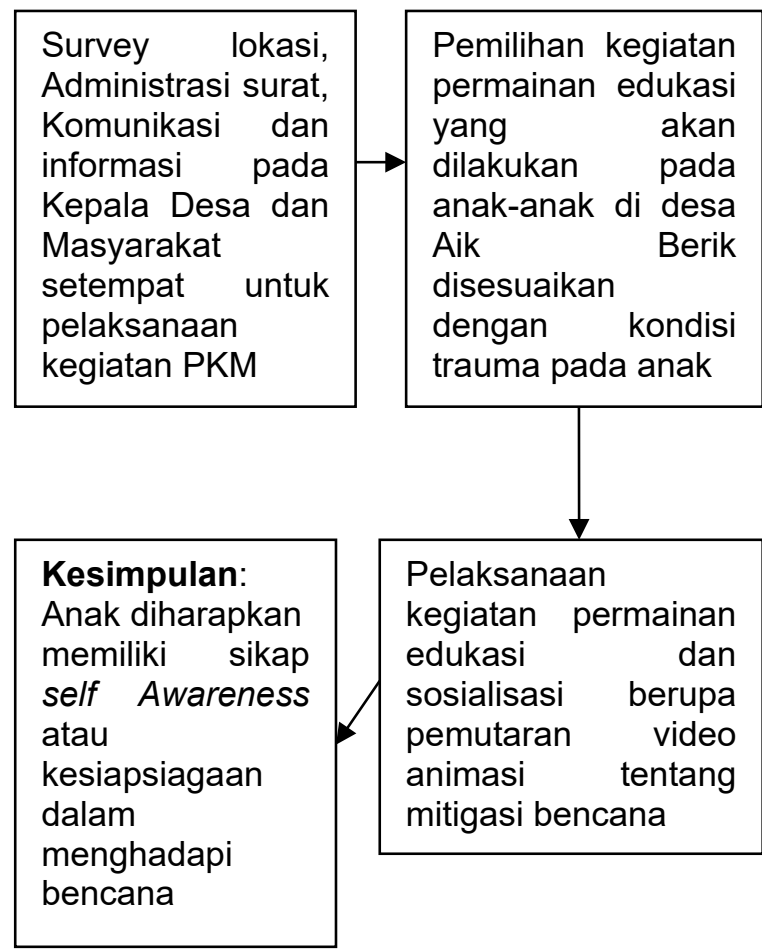

Gambar 1.Tahap Pelaksanaan Kegiatan PKM

Berikut ini adalah tahapan dari pelaksanaan kegiatan teknis yang sedianya akan dilaksanakan sebagai berikut:

1. Terlebih dahulu mengadakn survey lokasi terdampak, membuat surat ijin kepada kepala desa Aik Berik Kecamatan Batukliang Utara Kabupaten Lombok Tengah dengan melakukan komunikasi dan informasi terkait waktu dan jadwal kegiatan yang pastinya disesuaikan dengan kebutuhan dan kondisi desa setempat.

2. Melakukan pemilihan kegiatan permainan edukatif yang sesuai dengan kondisi dan karakter anak-anak di Desa Aik Berik Kecamatan Batukliang Utara Kabupaten Lombok Tengah yang disesuaikan dengan kondisi traumatik yang dialami anak-anak saat bencana tahun lalu yang masih berimbas sampai saat pelaksanaan survey lokasi kegiatan pengabdian pada masyarakat.

3. Melaksanakan kegiatan sosialisasi tentang mitigasi bencana pada guru dan anak-anak sesuai jadwal yang telah ditentukan dalam hal ini pemutaran video bencana yang dipublikasi dan dirilis tahun 2017 oleh Lembaga Penanggulangan Bencana Muhammadiyah Disaster management Center (MDMC) Pusat Muhammadiyah dengan menggunakan animasi disertai dengan pemaparan bencana yang terjadi seperti gempa bumi, tanah longsor, banjir, gunung meletus dan kebakaran sehingga diharapkan anak-anak memiliki pengetahuan tentang bencana dan memiliki sikap self awareness atau kesiapsiagaan tentang hal tersebut.

\section{HASIL DAN PEMBAHASAN}

Berdasarkan data resmi yang dilansir Pemerintah kabupaten Lombok Tengah, kabupaten ini terdirii dari 12 kecamatan, 12 kelurahan, dan 127 desa. Pada tahun 2017, jumlah penduduknya mencapai, 1.035.355 jiwa dengan luas wilayah 1.095,03 km2 dan sebaran penduduk 945 jiwa/km2. Desa Aik Berik adalah salah satu desa yang terletak di Kecamatan Batukliang Utara, kabupaten Lombok Tengah, Provinsi Nusa Tenggara Barat. Desa Aik Berik merupakan desa yang diresmikan sebagaii desa yang menjadi jalur pendakian Gunung Rinjani karena desa ini berbatasan dengan desa--desa yang berbatasan dengan hutan konservasii yang mengalami kerusakan akibat gempa sejak akhir Juli sampai bulan Nopember tahun 2018 lalu yaitu tercatat 180 rumah warga yang rusak diakibatkan oleh gempa yang berskala 7 skala richter (SR) walaupun skala kerusakan gempa yang lebih besar yang terjadi di kabupaten Lombok Utara lebih menjadi perhatian. Namun jalur pendakian satu-satunya yang dapat dilewati pasca gempa hanya di Desa Aik Berik yang dapat dilalui melewati hutan alam yang bagus. 


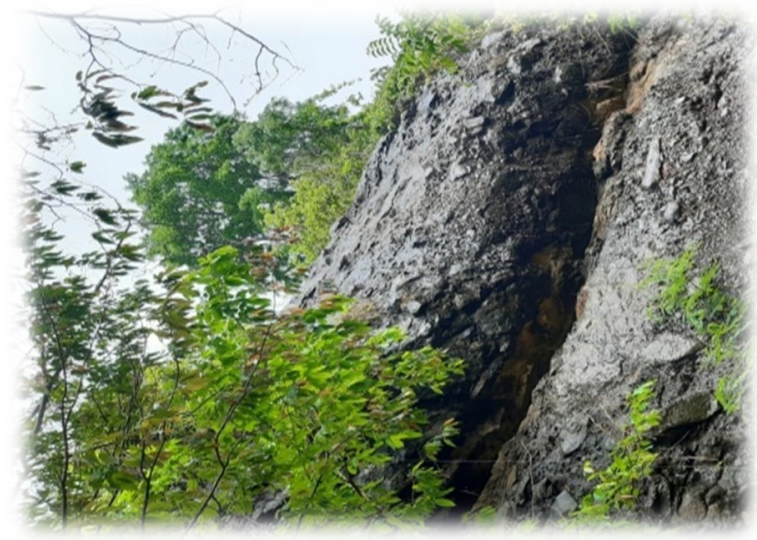

Gambar 2. Kondisi Hutan Alam Pasca Gempa Bumi.

Meski skala kerusakan gempa di daerah ini tidak separah dan sebesar getaran di Lombok Utara, namun aktivitas masyarakat desa yang lebih banyak bermatapencaharian sebagai petani sempat terganggu. Usahausaha yang dilakonii para petani petani dan kelompok usaha lainnya secara bersama pun sempat terhenti. Di beberapa lokasi bencana lain, para korban harus dibantu penuh untuk kebutuhan logistiknya, sehingga dapat dikatakan bahwa kondisi desa Aik Berik belum sepenuhnya pulih pasca gempa. Hal inilah yang kemudian menjadi alasan dipilihnya desa ini menjadi desa tujuan kegiatan pengabdian pada masyarakat ini dikarenakan letak desa yang harus segera dipulihkan dimana desa ini memiliki hutan yang amat berdaya guna dengan hasil yang dapat dikatakan cukup melimpah dan merupakan desa tujuan wisata yaitu air terjun Benang Stokel dan Kelambu yang ramai dikunjungi karena keasliannya dan juga di musim penghujan akan ada air terjun Dewi Anjani dan Umar Maya. Anak-anak di desa Aik Berik yang menjadi tujuan dari kegiatan ini bersekolah di SD Negeri Pemotoh Tengak yang memiliki siswa sebanyak 123 orang, SD Negeri Tambing Kekeq yang memiliki siswa sebanyak 59 orang dan juga ada PKBM (Pusat Kegiatan Belajar Bersama) sehingga dapat dikatakan anak-anak di desa ini untuk yang usia dini dan sekolah dasar jumlahnya cukup banyak namun saat pelaksanaan kegiatan yang dilaksanakan tim pengabdian yang hadir dan datang di Kantor Desa hanya sebanyak 35 orang saja yang terdiri dari usia anak dini, taman kanak-kanak, sekolah dasar dan sekolah menengah.

Oleh karena itu, tim pengabdian kemudian melaksanakan kegiatan PKM untuk mengurangi dan menghilangkan trauma pada anak-anak yang terdampak gempa ni dengan melakukan beberapa kegiatan permainan edukasi psikososial sebagai langkah-langkah mitigasi bencana.

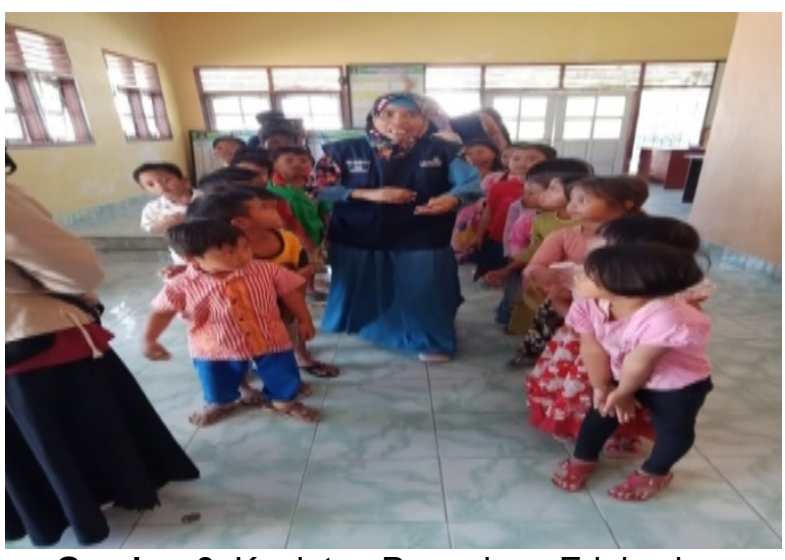

Gambar 3. Kegiatan Permainan Edukasi Psikososial Sirkuit dan Ketangkasan.

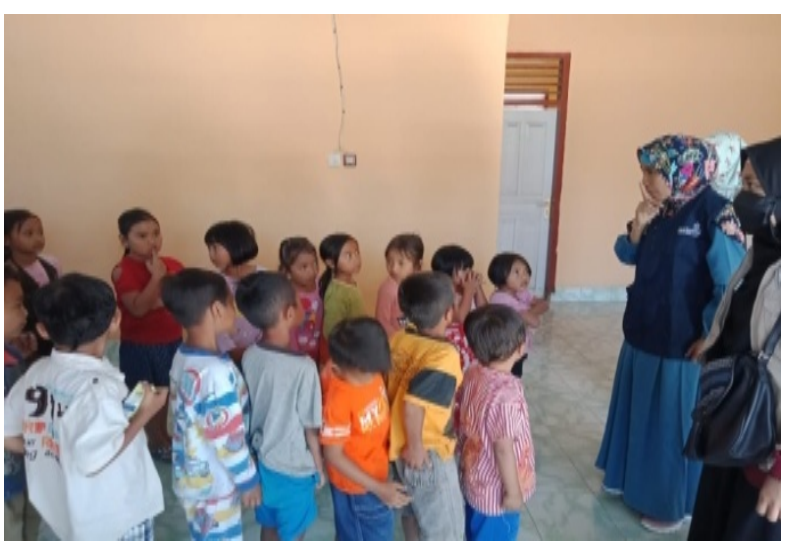

Gambar 4. Kegiatan Permainan Edukasi Psikososial Pesan Berantai in English.

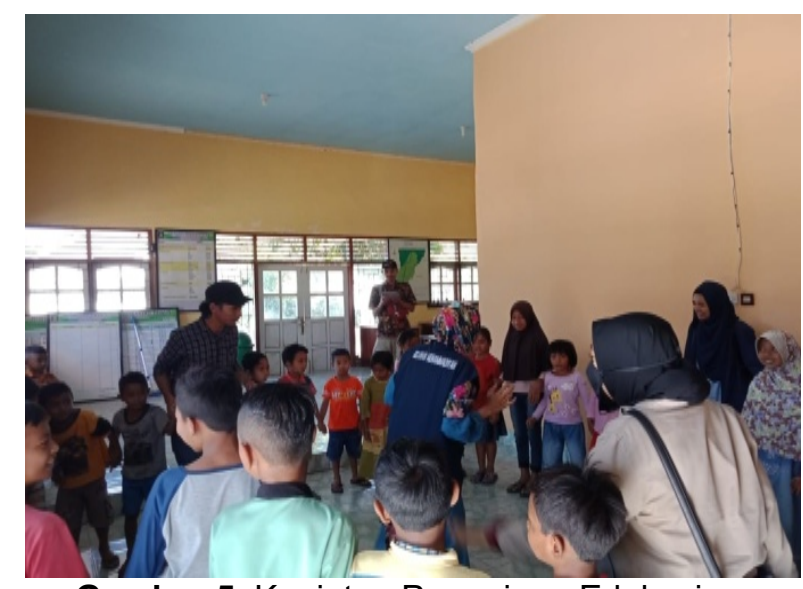

Gambar 5. Kegiatan Permainan Edukasi Psikososial Bermain Peran. 


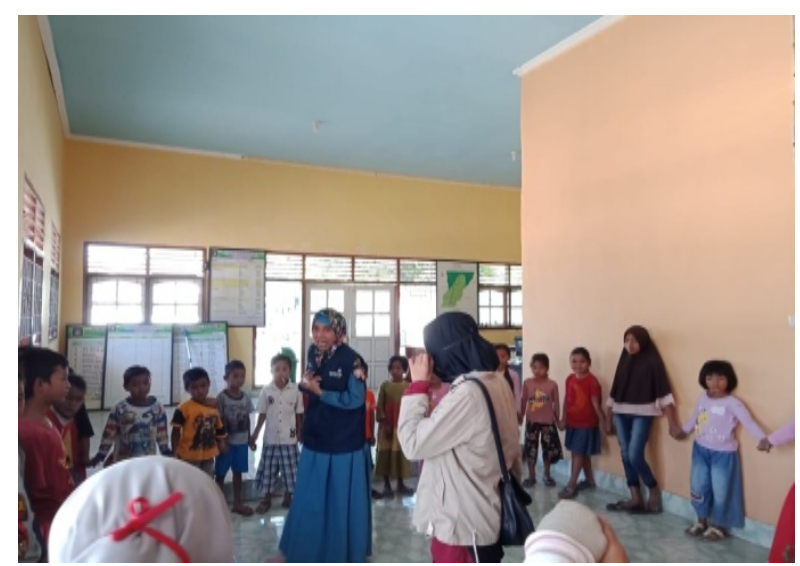

Gambar 6. Kegiatan Permainan Edukasi Psikososial Bermain Peran

Adapun hasil capaian dan luaran yang dihasilkan dalam kegiatan ini sebagai berikut:

a. Adanya pemahaman yang lebih baik tentang mitigasi bencana pada anak-anak dan masyarakat yang datang menemani anakanak mereka untuk meningkatkan self awareness mereka tentang bencana baik melalui permainan edukasi yang dilaksanakan dan begitu pula dengan sosialisasi dengan diputarkannya video animasi kebencanaan.

b. Dimilikinya pengembangan ilmu pengetahuan, keterampilan dengan menggunakan permainan edukatif atau edukasi untuk mengurangi dampak psikologis atau rasa trauma (trauma healing) akan dampak gempa yang terjadi pada tahun 2018 lalu yang masih membekas sampai saat pelaksanaan kegiatan pengabdian pada masyarakat ini.

c. Dimilikinya pengetahuan dan pemahaman tentang self awareness atau kesiapsiagaan akan mitigasi bencana yang bertujuan mengurangi dampak bencana atau usahausaha yang dilakukan untuk mengurangi resiko bencana ketika bencana terjadi baik korban jiwa maupun harta.

\section{SIMPULAN DAN SARAN Simpulan}

Dalam kegiatan pengabdian pada masyarakat ini dapat ditarik simpulan bahwa

1. Kegiatan permainan edukasi yang diberikan pada anak-anak dengan berbagai permainan seperti bermain peran atau role play tentang kebencanaan, permainan sirkuit dan ketangkasan, dan lainnya di desa Aik Berik Kecamatan Batukliang Utara Kabupaten Lombok Tengah dapat dikatakan mengurangi dampak psikologis atau rasa trauma diakibatkan oleh adanya bencana gempa bumi di tahun 2018 yang berskala 7 skala richter (SR) dimana mereka terlibat secara aktif berpartisipasi dalam kegiatan permainan edukasi yang dilaksanakan oleh tim pengabdian pada masyarakat ini.

2. Kegiatan sosialisasi dengan melakukan pemutaran video animasi tentang kebencanaan dalam bentuk fim yang berjudul "Aku Anak Siaga Bencana" yang disesuaikan dengan usia anak-anak yang terlibat dalam kegiatan ini sehingga diharapkan dapat memberikan pengetahuan dan pemahaman tentang self awareness atau kesiapsiagaan terhadap bencana baik bencana gempa bumi, banjir, tanah longsor, gunung meletus dan kebakaran.

\section{Saran}

1. Diperlukan adanya sinergitas dalam pelaksanaan kegiatan pengabdian pada masyarakat yang tidak hanya dilakukan di desa ini dengan menyesuaikan kegiatan yang ada di desa sehingga tujuan dari pelaksanaan kegiatan dapat berhasil dan berguna bagi semua pihak yang terlibat.

2. Perlunya dibuat surat kesepakatan dan kesepahaman dalam semua pelaksanaan kegiatan yang akan dilaksanakan di desa sehingga memudahkan semua pihak dan dapat menguntungkan pula, dengan kata lain bisa dibuat desa binaan sebagai desa percontohan kampus UMMAT untuk pelaksanaan kegiatan baik penelitian maupun pengabdian pada masyarakat.

\section{DAFTAR RUJUKAN}

Basyaruddin, Yosi, dan Abdillah Obid. (2004). Manhaj pendidikan Anak Muslim. Jakarta Selatan: Mustaqim

DP2M Dikti. (2017). Buku Panduan Pelaksanaan Penelitian dan Pengabdian Kepada Masyarakat Edisi XI Tahun 2017. Jakarta.

Flurentin, Elia. (2014). Latihan Kesadaran Diri (Self Awareness) Dan Kaitannya Dengan Penumbuhan Karakter. Jurnal Inspirasi Pendidikan Universitas Kanjuruhan Malang, 1(1). 9.

Harsono. (1988). Coaching Dan Aspek-Aspek Dalam Coaching. Jakarta: Departemen Pendidikan dan Kebudayaan.

Ismail, Andang. (2007). Education Games: Menjadi Cerdas dan Ceria dengan Permainan Edukatif. Yogyakarta: Pilar Media

LPM UM Mataram. (2018). Pedoman Pengabdian Kepada Masyarakat dan Prosedur Penulisan Proposal. Universitas Muhammadiyah Mataram

Morin, Alain. (2011). Self-Awareness Part 1: Definition, Measures, Effects, 
Functions, and Antecedents. Mount Royal University Social and Personality Psychology Compass 5/10

Musbikin, Imam. (2006). Mendidik Anak Kreatif ala Einstein. Yogyakarta: Pustaka Pelajar

Ningtyas, Dhita Paranita. (2018). Pengembangan Permainan Sirkuit Mitigasi Bencana Gempa Bumi Untuk Meningkatkan Self Awareness Anak Usia Dini. Jurnal Caksana-Pendidikan Anak Usia Dini. 1(2). 